\title{
Overview and classification of housing forms intended for older and disable people occurring in high-developed countries in context to deficit of similar forms in Poland
}

\author{
Monika Magdziak \\ e-mail:m.magdziak@pb.edu.pl \\ Faculty of Architecture, Bialystok University of Technology \\ The research was carried out as part of work no. S/WA/2/16 and funded by polish Ministry of Science and Higher Education.
}

\begin{abstract}
In most highly developed countries, in addition to services and home care system, there are various forms of housing with care and services for the elderly and the disabled. In this work, the author presents the effect of searching for various housing solutions in a brief description of residential forms. A classification of recognized housing models was prepared in the form of a summarizing table, in which groups of housing forms with similar characteristics were selected, and assigned to groups of residents with different level of disability and independence. In addition, the author systematizes the terminology in English-language publications and presents general conclusions from the conducted research in the context of a deficit of similar to the presented solutions in Poland.
\end{abstract}

Key words: architecture, housing, care, elderly, disabled people, intermediate housing forms;

\section{Introduction}

Analyzes and demographic projections for Poland show a very intensive process of population aging, which progresses much faster than in Western Europe, where this process began much earlier and is at an even more advanced stage. Along with demographic changes in Poland, there are social changes in the model of the traditional family, which will result in a drastic decline in the family welfare potential in the coming years, on which the social welfare system in Poland is currently based. In the perspective of ongoing transformations, the greatest and most urgent challenge is to provide help and care to dependent elderly and disabled people, and to provide living conditions and services that will extend the period of their psycho-physical fitness and functional independence. Not only the increase in the number of older people in society, but above all the lack of family care is becoming the main factor influencing the growth of demand for special housing forms for the elderly and disabled, which require support or daily care. Faced with this situation, new challenges for social and housing policy in Poland arise. They concern the extension of the offer of caring and housing forms for the elderly and the disabled, both in quantitative and qualitative terms. Considering that other highly developed countries have encountered this problem earlier and have already implemented housing models and support systems for dependent people, it is important to get to know and analyze these solutions that can be the basis for developing standards adequate to the scale of needs and preferences of older and disabled people in Poland. 


\section{Research goals, tasks and methods}

Considering the fact that Polish seniors, in terms of their needs and preferences, are becoming more and more similar to seniors in other highly developed countries, and demographic projections indicate that in the coming decades the proportions of age groups in the European Union countries will be very similar - the main scientific goal has become the search for various patterns and solutions accepted in other countries that could be helpful in predicting the directions of changes in housing for the elderly and the disabled in Poland. The indirect goal was to systematize the various terminologies appearing in English-language publications. The paper contains an overview of housing forms for the elderly and the disabled appearing in the framework of the Polish social welfare system. The author also presents general conclusions from the conducted research on housing solutions occurring in highly developed countries, in the context of the deficit of such solutions existing in Poland.

\section{Results of research}

The paper presents the current results of the conducted research in the form of a concise characterization of the identified groups of special housing forms for elderly and the disabled people. A classification was also developed in which groups of special housing forms with similar characteristics were selected, and assigned to groups of residents with different health and independence levels.

\section{Discussion}

\section{System of stationary long-term care in Poland}

In Poland, care for the elderly and the disabled is included in the social welfare system. The most common form of residential care are Social Care Homes (in polish - domy pomocy społecznej - DPS) run by local self-government bodies, associations and religious gatherings. Persons who are in need of intensive care because of age, illness or disability and who are unable to function independently can apply for residence in these special housing forms. The current law distinguishes several types of homes to which adults are addressed: for the elderly, for the chronically ill people, for the chronically mentally ill, for people with physical disabilities, and for people with intellectual disabilities. The regulations allow to combine certain types of houses. ${ }^{1}$

The stationary care sector also includes facilities providing 24-hour care on a commercial basis as part of business or statutory activities. They are colloquially called "private" care homes and are very similar in terms of organization and scope of services offered to social welfare homes ${ }^{2}$. Only the standards that these institutions must meet are different. The guidelines are quite general ${ }^{3}$, so the level and range of care services is strictly dependent on the amount of fees paid in full by residents.

Another form of care for people in need of round-the-clock care due to advanced age are Family Care Homes (in polish - rodzinne domy pomocy - RDP), providing services for 3-8 residents, in the carer's place of residence. ${ }^{4}$ The first facilities of this type started operating in 2003 , so it is still a relatively new form of housing for older people. Maintaining a resident in a family home is much cheaper than in Social Care Homes (DPS), mainly due to the smaller range of services provided. For the same reason, people who do not require constant nursing care are directed here. Persons running such a house do not need to have education in this direction. Unfortunately, only a few Family Care Homes have been operating in Poland over the last years. The research

2 Z. Szweda-Lewandowska, The forecast of the demand for places in social welfare homes for people aged 75 and over, [in:] Aging of the Polish population. Between demography and social gerontology, edited by J.T. Kowalewska, P. Szukalski, Lodz 2008, p. 138; (in polish).

3 According to the regulations, the manner and scope of service provision should include: "health, physical and intellectual fitness as well as individual needs and abilities of residents", Social Welfare Act of 12 March 2004 (Chapter 3, Article 68); (in polish).

4 Regulation of the Minister of Labor and Social Policy of October 17, 2001 on family care houses, Dz.U. No. 127 item 1399; (in polish). 
of Supreme Audit Office (in polish - Najwyzsza Izba Kontroli - NIK) shows that most local governments are not interested in developing this form of 24-hous care for elderly and disabled people. ${ }^{5}$

The Act of 12 March 2004 on social assistance also introduced the possibility of organizing Sheltered Apartments (in polish - mieszkania chronione) for the elderly and the disabled, which require support in functioning in everyday life, but do not need 24 -hour care. ${ }^{6}$ Sheltered Apartments are designed to replace a stay in a facility providing 24-hour care. According to the current regulations, they are designed for a minimum of 3 people, and the maximum number of residents is not specified. ${ }^{7}$ These are more like collective, group and not individual apartments. This solution allows to significantly reduce housing costs, and increase the independence of residents based on mutual assistance between them. Also for the local government this form of social assistance is financially more beneficial than creating and maintaining 24-hour care homes. Sheltered apartments can be organized as part of a social care home program. Unfortunately, in polish practice, this form of housing was almost not available to the elderly and the disabled.

\section{Forms of housing for the elderly and the disabled appearing in other highly developed countries}

In the majority of highly developed countries, affected by the problem of population aging, apart from services and the home care system, there are various forms of housing with care or services for elderly and disabled people. These are both collective buildings (such as a polish social care home), but also multi-apartment buildings, housing communities, as well as entire housing estates and villages for the elderly and disable. Knowledge about them is, however, disordered. In the subject literature and Internet sources there are different names and classifications. For the purpose of this study, a division of housing forms for older people was proposed, depending on the level of independence of residents. Housing forms for the elderly and the disabled were divided into the following forms: with service, with care, with long-term care, housing for people with dementia, and housing complexes with continuity of care, combining several of the above forms (Fig.1.)

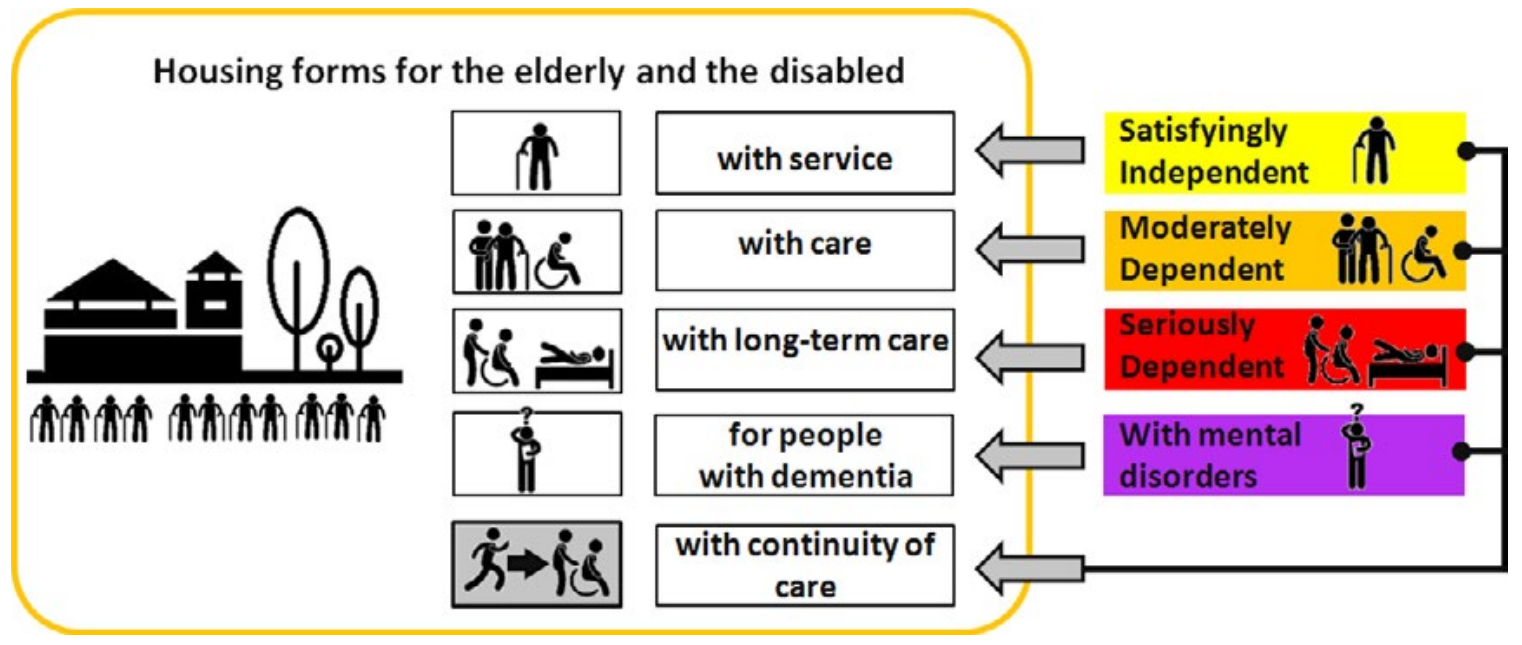

Fig. 1. Division of housing forms for older and disable people, depending on the level of independence of residents, author's work.

Podział form mieszkaniowych dla osób starszych i niepełnosprawnych w zależności od poziomu samodzielności, opracowanie autorskie.

5 E. Wesołowska, Running social assistance homes is unprofitable, Dziennik Gazeta Prawna, http://praca.gazetaprawna.pl/artykuly/595837, prowadzenie domow_pomocy_spolecznej_jest_nieoplacalne.html (21.02.2012); (in polish).

6 Dz. U. No. 64, item 593 with changes art.53; (in polish).

7 Dz. U. of 22 March 2012, item 305; (in polish). 


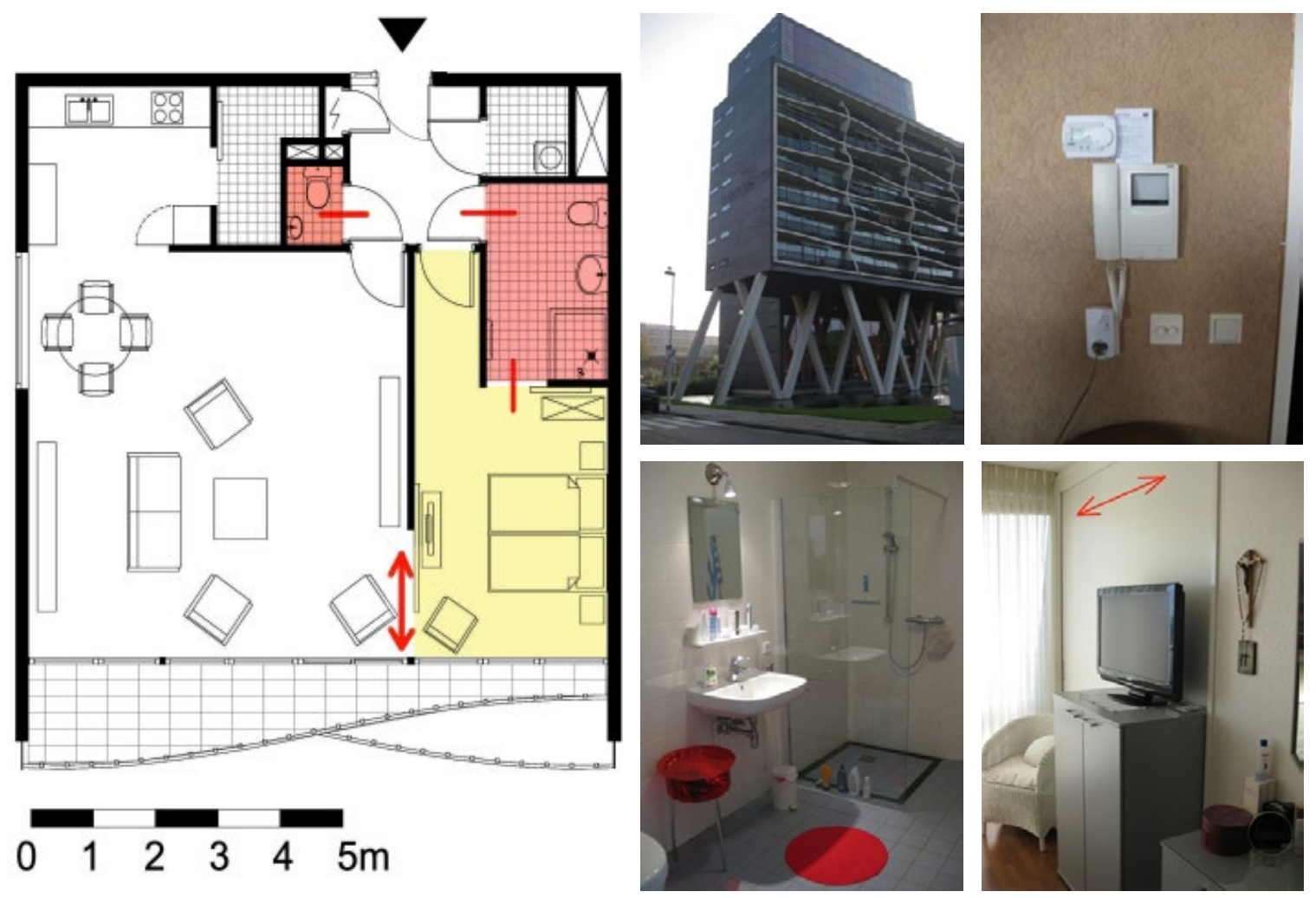

Fig. 2. An example of a flat with service - with one bedroom. The bedroom is connected, with the living room through mobile walls. Bathroom connected to the bedroom by additional sliding doors. De Plussenburgh, Rotterdam, the Netherlands. Graphic and photo - author.

Przykładowe mieszkanie z serwisem - z jedną sypialnią. Sypialnia łączona jest w zależności od potrzeb z salonem poprzez mobilne ścianki. Łazienka połączona z sypialnią za pomocą dodatkowych przesuwanych drzwi. De Plussenburgh, Rotterdam, Holandia. Opracowanie graficzne i fot. Autorki.

Housing forms with service - this is a grouping of individual flats (Fig. 2.). Elderly and disabled people live completely independently and can, depending on the needs, use the cleaning service, meals delivered to the apartments or served in the common dining room, organized educational, recreational or rehabilitation activities and other services that are designed to enable the longest independent functioning. They are intended for people who are independent, in a period of full or satisfactory state of health, do not require constant care, but only relieve from daily duties, or need to improve the level of social contacts and a sense of security. Housing forms with the service create independent groups or are more often integrated with a care facility within a single building or a housing complex.

- Independent groups of apartments with service can be in the form of a multi-apartment building with a separate common area or they can form a group of houses (mostly terraced houses) with a common part located in a separate facility located mostly in the central part of the complex. As part of such a group of apartments, there may also be commercial services such as a shop, a café, a hairdresser or a dentist. The offer does not include long-term care and medical care, although it happens that the complex has a medical clinic also available for people living in the local environment. In English-language publications, independent groups of apartments with service appear under the name of: Congregate/Sheltered housing - small social, one and two-room apartments, rented by older people over 55 or 60 years old ${ }^{8}$; Residential/Independent Living Apartments - flats and condominiums with a variety of standards and number of rooms ${ }^{9}$. 
- Apartments with a service integrated with a care facility - this is a form of social housing and rental apartments, located in a separate part of the building or in a separate building on a shared plot next to a care facility. The apartments are completely independent, but integrated with Care Call and Alert Systems. Residents can use the site, commercial services, and sometimes also rehabilitation, and various types of activities in the care facility. In the English-language publication it is known as Close Care Housing ${ }^{10}$.

Housing forms with care - these forms of housing are intended for people in a period of limited health, when there are difficulties in performing everyday activities, such as bathing, dressing, washing, eating, cleaning, taking medicine - for people in need of daily help, but not requiring 24-hour medical care. Housing forms with care occur in the form of a multi-dwelling building or in the form of a collective residence building. In both cases, the residential area is expanded to include common rooms, social services, care and rehabilitation programs, administration rooms and commercial functions.
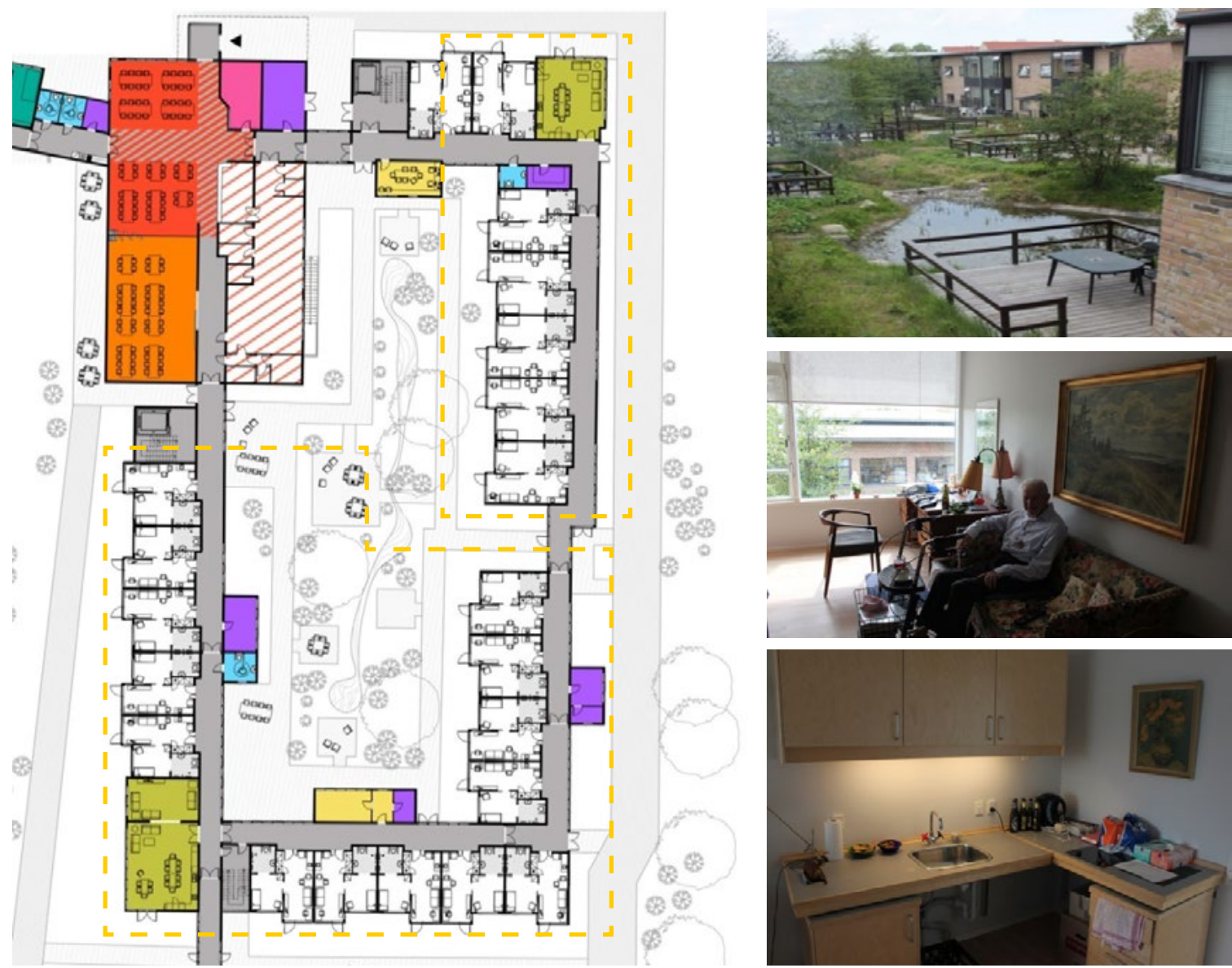

Fig. 3. Housing form with care - groups of flats with additional common spaces and staff points (marked with dotted line). The division is also reflected in the body of the building. Common areas include terraces. Rosenlund, Mørkhøjvej, Denmark. Graphic and photo - author.

Forma mieszkaniowa z opieką - grupy mieszkań uzupełnione o wspólne przestrzenie i stanowiska personelu (oznaczone linią przerywaną). Podział jest również odzwierciedlony w bryle budynku. Przy pomieszczeniach wspólnych znajdują się tarasy. Rosenlund, Mørkhøjvej, Dania. Opracowanie graficzne i fot.autorki.

- In a multi-apartment building, older people live in individual small, one and two-room flats, equipped with a kitchenette and a bathroom. Choosing this form of housing allows older people to maintain full privacy 
and a sense of independence. It is a form of housing offering smaller apartments, but a higher level of care than in housing forms with service. Flats are divided into groups with dedicated day zone in which residents consume meals and spend time (Fig. 3). In English-language publications, they appear under the name Assisted Living Apartments (Am.), Extra Care Housing, Very Sheltered Housing (Eng.) ${ }^{11}$.

- In collective buildings, residents occupy individual rooms with bathrooms, which are part of the housing groups (8-12 rooms with a shared common day zone) or composition of collective apartments, where 6-10 inhabitants share the day zone of the flat - living room, kitchen, dining room (Fig. 4.). Residents have smaller private space. This model is the closest in terms of the scope of care and services, organizational solutions and characteristics of residents, to Polish Social Care Homes for the elderly (DPS) ${ }^{12}$. In contrast to these solutions, in Poland, residents usually live in two, three and even four-person rooms, less often individually. The rooms are arranged along long corridors, without division into groups. In English-language publications, they appear under the name - Assisted Living Facility, Assisted Living Residences, Personal Care Homes, Residential Care Facility, Adult Homes, Retirement Residences, Adult Congregate Living (Am.), Care Homes, Residential Homes, Homes for the aged, Rest Homes (Eng. $)^{13}$.

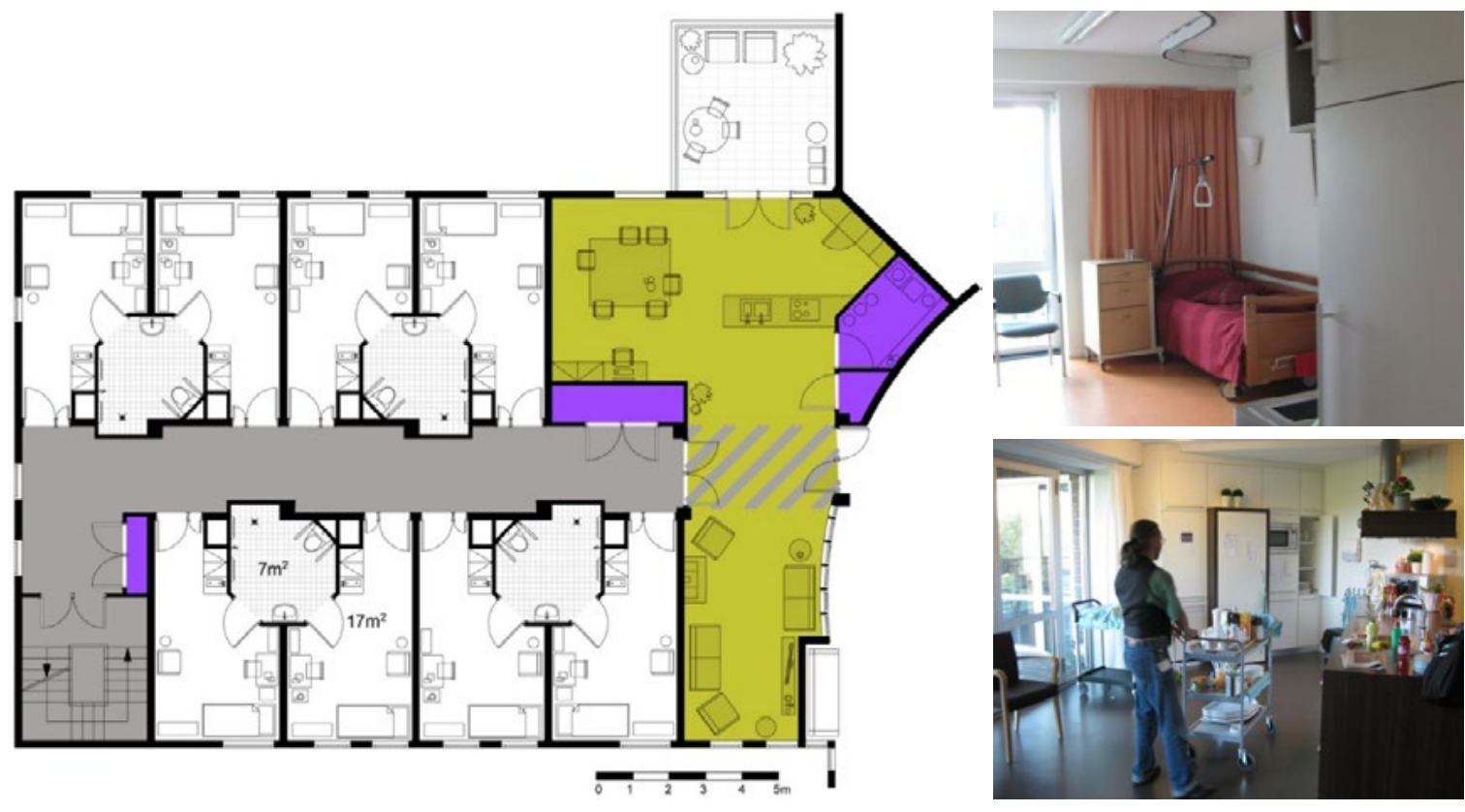

Fig. 4. Housing form with care - A group apartment for eight older people. De Maarteshof, Groningen, Netherlands. Graphic and photo - author.

Forma mieszkaniowa z opieką - Mieszkanie grupowe dla ośmiu osób starszych. De Maarteshof, Groningen, Holandia. Opracowanie graficzne i fot. autorki.

Housing forms with long-term care - this is a form of residence based on the model of 24-hour nursing care, on seriously ill, dependent and disabled people. Usually, they are people lying or moving in wheelchairs with the help of caregivers. Residents usually stay in single and double rooms with bathrooms. Due to the fact that most of residents spend the most part of the day in their own room, the residential area is expanded only by a small program of common and rehabilitation rooms. It is the model most similar in terms of care to the polish Care and Treatment Facilities (in polish - zakłady opiekuńczo-lecznicze - ZOL) or Nursing and Care Facilities (in polish -zakładów pielęgnacyjno-opiekuńczych - ZPO), whose tasks and competences are subject to

11 D. Hughes, S. Judd, Design for Aging: International Case Studies of Building and Program, John Wiley \& Sons, 2012, p. $275-276$.

12 DPS - Dom Pomocy Społecznej - registered name, obligatory in Poland since 2004, Dz. U. 2004 No. 64, item 593.

13 K. Christensen, Encyclopedia of Community: From the Village to the Virtual World, Sage Publications, 2003, pp. 427-430; D. Hughes, S. Judd, op. cit., pp. 275-276. 
medical care and go beyond the scope of social care. In Poland, due to the lack of places in the above-mentioned facilities, in many Social Care Homes for somatically ill persons, nurses are employed as caregivers. Among the residents, we meet people who do not leave the bed and use specialist medical equipment. Therefore, it can be said that the real, Polish equivalent of this form of housing are Social Care Homes for somatically ill people. In English-language publications, they appear under the name - Care Homes with nursing, Nursing Homes (Eng.), Skilled Nursing Facilities, Long-Term Care Facilities (Am. $)^{14}$.
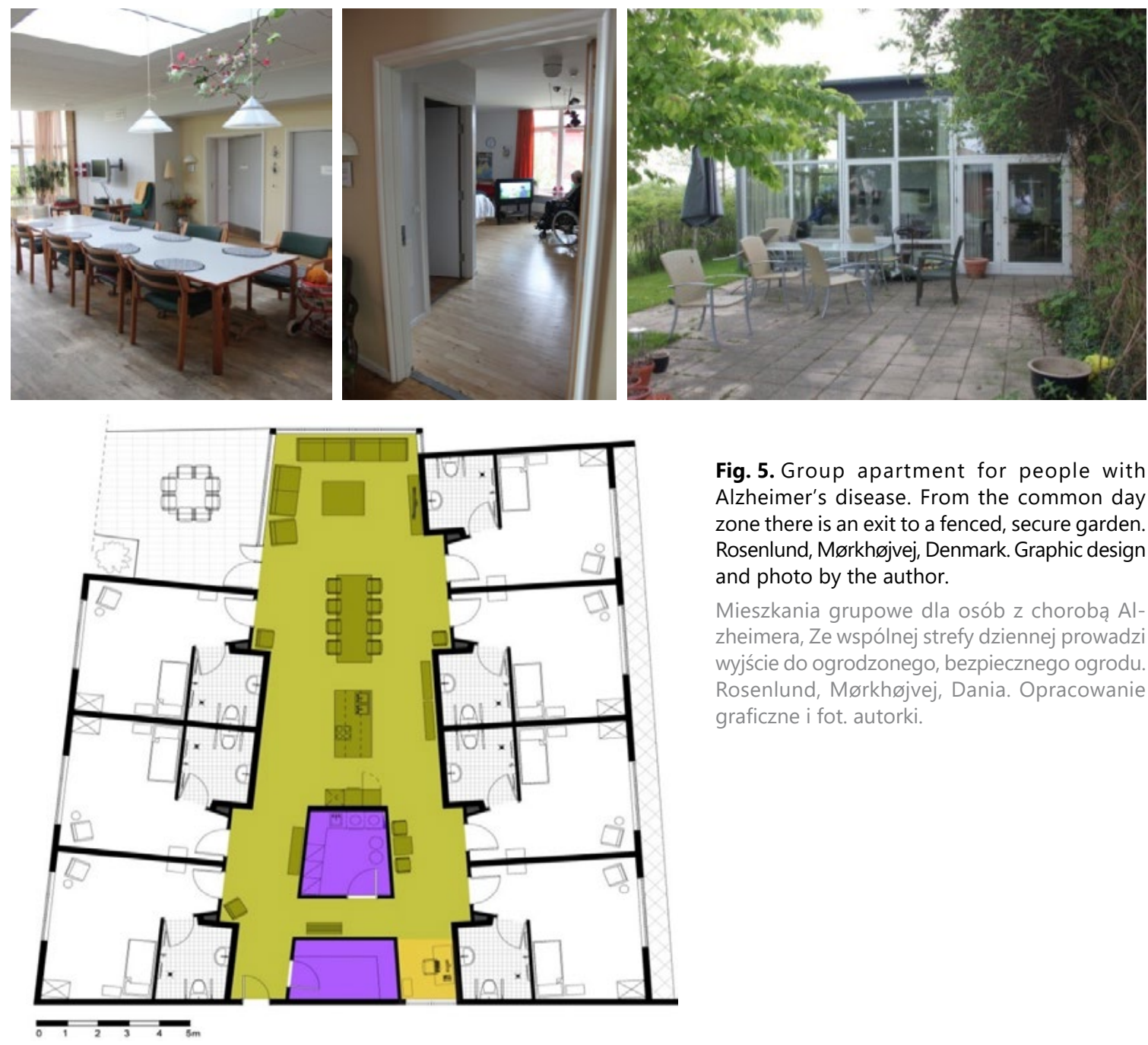

Fig. 5. Group apartment for people with Alzheimer's disease. From the common day zone there is an exit to a fenced, secure garden. Rosenlund, Mørkhøjvej, Denmark. Graphic design and photo by the author.

Mieszkania grupowe dla osób z chorobą Alzheimera, Ze wspólnej strefy dziennej prowadzi wyjście do ogrodzonego, bezpiecznego ogrodu. Rosenlund, Mørkhøjvej, Dania. Opracowanie graficzne i fot. autorki.

Housing for people with dementia - it is a special form of housing for diverse group of older people with disorders of cognitive processes, personality, memory and intellect. The most common form of dementia is Alzheimer's disease. Most people with dementia are people with a satisfactory degree of physical fitness, but due to mental disorders, requiring supervision and assistance in many daily activities. The facilities existing in other highly developed countries are either closed facilities or isolated safe parts of residential complexes with care. They have very diverse functional and spatial programs, which results from insufficient knowledge about proven solutions suitable for people with dementia. Designers are constantly looking for new space models that will provide a safe and intellectually stimulating housing environment ${ }^{15}$. The in-situ study shows that the 
most favourable form of housing development for people with dementia is the creation of small objects (25-30 people) located in the natural environment, and in larger buildings, a division into housing groups for a maximum of 8-10 inhabitants, where each person has an individual room with a bathroom and shares the day zone with other co-residents (Fig. 5.). This solution allows keeping small scale of rooms and reducing space, which eliminates the feeling of being lost. The indicated extensions of the residential area are rooms to occupational therapy and a secure, fenced garden. Apart from the isolated housing zone, other functions are located, including rooms for rehabilitation ${ }^{16}$. In Poland, due to the lack of dedicated examples of Social Care Homes for people with Alzheimer's disease, such people are usually directed to care facilities for mentally ill people. In addition, in all Social Care Homes for the elderly and somatically ill, we meet people with Alzheimer's disease, which has already appeared during the stay in the facility. In English-language publications, they appear under the name - Dementia Care Homes, Nursing Homes for Alzheimer's (Eng.), Alzheimer's Nursing Home, Dementia Care Facilities, Alzheimer Special Care Units (Am. $)^{17}$.

Housing forms with continuity of care - they consist of several previously discussed forms of housing for the elderly and disabled, corresponding to the subsequent stages of care. As the health condition deteriorates, residents within the same housing community move to housing forms offering a higher level of care. By placing different housing models in one place, it is possible to ensure continuity of care and preserve the idea of aging in the same place where you live for years, regardless of the deteriorating health condition of residents, until the end of their days. The combination of various forms of housing into a larger one offers the opportunity to propose more diverse spaces, a richer offer of services, and to integrate seniors at various stages of old age. Individual housing forms can be located in one building or located on the same building plot next to each other. In the United States of America, housing forms with continuity of care are classified into: small - up to 200 inhabitants, medium - from 200 to 400 inhabitants, and large - over 400 inhabitants. ${ }^{18}$ In English-language publications, they appear under the name - Continuing Care Retirement Communities (Am.), Retirement Care Villages (Eng. $)^{19}$.

\section{Summary}

As a summary of the conducted research, a classification of recognized and characterized forms of housing for the elderly and the disabled in other countries was developed (Table 1). Groups of special housing forms with similar features were selected, and assigned to the recipient groups of varying degrees of health and level of independence in life. The assignment of users to residential forms is aimed to point out an appropriate housing environment that will provide services and care at a level adapted to the level of functional level of dependence of residents. The disadvantage is to live in a place that is not sufficiently adapted to the needs of the resident, but also if the level of care and services exceeds its capabilities, which may accelerate the process of functional dependence.

\section{Conclusions}

In Poland, the most common form of residential care for the elderly and the disabled are currently Social Care Homes and "private" care homes. The availability of places and the housing standard offered in them is insufficient and inadequate to the needs. Other forms of housing operating within the framework of social assistance are Sheltered Apartments and Family Care Homes. Seniors have difficult access to them, and number of places designed for them is marginal. It is necessary to develop new patterns of formal care that will reduce the need for places in care facilities. This is possible by introducing new forms of housing, similar to the forms available in other countries previously affected by the phenomenon of an aging population. Introduction of

\footnotetext{
16 B. Schwarz, R. Brent, Aging, Autonomy, and Architecture: Advances in Assisted Living, JHU Press, 1999, p.17-18.

17 E.C. Brawley, op. cit., p. 41-47.

18 B. Perkins, , op. cit., p. 87.

19 S.Evans, Community and Aging, Maintaining quality of life In housing with care settings, The Policy Pres, 2009, p. 34
} 
Table 1. Classification of housing forms for the elderly and the disabled. Symbols: In column 4. - the destination group of inhabitants was distinguished with color, (+-) transition periods were determined between successive stages of old age, * Polish housing forms - intended for users with a similar degree of functional independence, but which may differ in terms of architectural solutions and operating principles.

Zestawienie zbiorcze form zamieszkiwania osób starszych. Oznaczenia: W kolumnie 4. - kolorem wyróżniono docelową grupę mieszkańców, (+ -) oznaczono okresy przejściowe między kolejnymi etapami starości, * polskie formy mieszkaniowe, przeznaczone dla użytkowników o podobnym stopniu sprawności i samodzielności funkcjonalnej, jednak mogące różnić się pod względem rozwiązań architektonicznych i zasad działania.

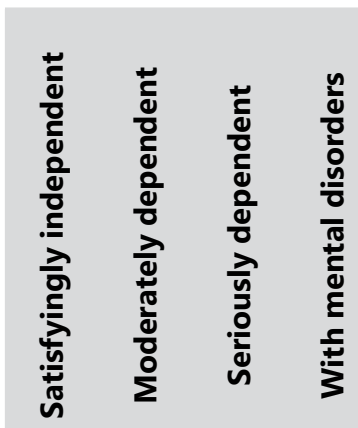

\begin{tabular}{|c|c|c|c|c|c|c|c|}
\hline \multicolumn{2}{|c|}{ 1. Housing forms } & \multirow{2}{*}{$\begin{array}{c}\text { 2. Names } \\
\text { Congregate housing, } \\
\text { Sheltered housing, } \\
\text { Residential Living Apartments, } \\
\text { Independent Living Apartments }\end{array}$} & \multirow{2}{*}{$\begin{array}{l}\text { 3. Polish housing } \\
\text { forms* } \\
\\
-\end{array}$} & \multicolumn{4}{|c|}{ 4. Profiles of residents } \\
\hline \multirow{2}{*}{ 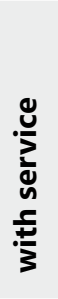 } & $\begin{array}{l}\text { Independent } \\
\text { groups of } \\
\text { apartments }\end{array}$ & & & + & + & - & - \\
\hline & $\begin{array}{l}\text { Apartments } \\
\text { integrated with } \\
\text { a care facility }\end{array}$ & Close Care Housing & - & + & + & - & - \\
\hline \multirow{2}{*}{$\begin{array}{l}\frac{0}{5} \\
\frac{2}{3} \\
\frac{5}{3}\end{array}$} & $\begin{array}{l}\text { In a multi- } \\
\text { apartment } \\
\text { building }\end{array}$ & $\begin{array}{c}\text { Assisted Living Apartments, } \\
\text { Extra Care Housing, } \\
\text { Very Sheltered Housing }\end{array}$ & - & + & + & $\begin{array}{l}+ \\
-\end{array}$ & - \\
\hline & $\begin{array}{l}\text { In collective } \\
\text { building }\end{array}$ & $\begin{array}{l}\text { Assisted Living Facility, } \\
\text { Assisted Living Residences, } \\
\text { Personal Care Homes, } \\
\text { Residential Care Facility, } \\
\text { Retirement Residences, } \\
\text { Adult Congregate Living, } \\
\text { Adult Homes, Care Homes, } \\
\text { Residential Homes, } \\
\text { Rest Homes, } \\
\text { Homes for the aged, }\end{array}$ & $\begin{array}{l}\text { Social Care } \\
\text { Homes for the } \\
\text { elderly (DPS) }\end{array}$ & + & + & - & $\begin{array}{l}+ \\
-\end{array}$ \\
\hline & h long-term care & $\begin{array}{c}\text { Care Homes with Nursing, } \\
\text { Nursing Homes, } \\
\text { Skilled Nursing Facilities, } \\
\text { Long-Term Care Facilities }\end{array}$ & $\begin{array}{c}\text { Care and } \\
\text { Treatment } \\
\text { Facilities (ZOL), } \\
\text { Nursing and Care } \\
\text { Facilities (ZPO), } \\
\text { Social Care Homes } \\
\text { for somatically ill } \\
\text { (DPS) }\end{array}$ & - & $\begin{array}{l}+ \\
-\end{array}$ & + & $\begin{array}{l}+ \\
-\end{array}$ \\
\hline & $\begin{array}{l}\text { or people with } \\
\text { dementia }\end{array}$ & $\begin{array}{l}\text { Dementia Care Homes, } \\
\text { Nursing Homes for Alzheimer's, } \\
\text { Alzheimer's Nursing Home, } \\
\text { Dementia Care Facilities, } \\
\text { Alzheimer Special Care Units }\end{array}$ & $\begin{array}{l}\text { Social Care Homes } \\
\text { for mentally ill } \\
\text { people (DPS) }\end{array}$ & - & + & + & + \\
\hline & $\begin{array}{l}\text { th continuity of } \\
\text { care }\end{array}$ & $\begin{array}{c}\text { Continuing Care Retirement } \\
\text { Communities, } \\
\text { Retirement Care Villages }\end{array}$ & - & + & + & + & + \\
\hline
\end{tabular}

Source: own study ${ }^{20}$ 
intermediate forms, i.e. flats with service and apartments with care, contributes to extending the period of independence of residents. This leads to lowering the demand for places in 24-hour care facilities. Polish law regulations regarding care facilities are so general that they enable the creation of various alternative forms of housing for the elderly and the disabled, which could fill the gap between home care and stay in a Social Care Home, offering seniors the conditions more homogeneous and close to independent living. However, it is necessary to provide organizational support and develop standards for various housing forms in Poland.

Based on experiences from other countries, general recommendations for existing social care homes in Poland can be indicated. They include:

- Improvement of housing conditions in terms of ensuring privacy and decision-making of residents,

- Improvement of the image of care facilities through integration with the local community,

- Improving the safety and freedom of life of residents with Alzheimer's disease,

- Extending the current form of Polish Social Care Homes with intermediate housing forms located in the surrounding,

- The division of larger forms of housing into clearly identifiable groups of a few residents, where scale and general character of space is closer to home conditions.

\section{Literature}

[1] Anderzhon J.W., Design for Aging: International Case Studies of Building and Program, John Wiley \& Sons, 2012.

[2] Brawley E.C., Design Innovations for Aging and Alzheimer's, Creating Caring Environment, Wiley \& Sons, 2006.

[3] Christensen K., Encyclopedia of Community: From the Village to the Virtual World, Sage Publications, 2003.

[4] Evans S., Community and Aging, Maintaining quality of life In housing with care settings, The Policy Pres, 2009.

[5] Hughes D., Judd S., Design for Aging: International Case Studies of Building and Program, John Wiley \& Sons, 2012.

[6] Magdziak M., Housing forms of elderly people, PhD thesis, Lodz, 2014. (in Polish)

[7] Perkins E., Building Type Basics for Senior Living, John Wiley \& Sons, 2013.

[8] Regulation of the Minister of Labor and Social Policy of 14 March 2012 in the matter of sheleterd housing, Dz. U. of 22 March 2012. (in Polish)

[9] Regulation of the Minister of Labor and Social Policy of October 17, 2001 on Family Care houses, Dz.U. No. 127 item 1399. (in Polish)

[10] Robson D., Nicholson A., N. Barker, Homes for the Third Age: A Design Guide for Extra Care Sheltered Housing, Taylor \& Francis, 1997.

[11] Schwarz B., Brent R., Aging, Autonomy, and Architecture: Advances in Assisted Living, JHU Press, 1999.

[12] Social Welfare Act of 12 March 2004, Dz. U. No. 64, item 539. (in Polish)

[13] Szweda-Lewandowska Z., Predictions of demand for places in social welfare homes for people aged 75 and over, [in:] Aging of the Polish population. Between demography and social gerontology, red. J.T. Kowalewska, P. Szukalski, Lodz 2008, p.138. (in Polish)

[14] Wesołowska E., Running social care homes is unprofitable, Dziennik Gazeta Prawna, http://praca.gazetaprawna.pl (21.02.2012). (in Polish)

[15] Yesalis C.E., U.S. Health Care: Principles and Perspectives, Cengage Learning, 2012. 


\section{Przegląd oraz klasyfikacja zespołów mieszkaniowych przeznaczonych dla osób starszych i niepełnosprawnych występujących w krajach wysokorozwiniętych w kontekście deficytu podobnych rozwiązań w Polsce}

Streszczenie: W większości krajów wysoko rozwiniętych, dotkniętych problemem starzenia się społeczeństwa, oprócz usług i systemu opieki środowiskowej (domowej), funkcjonują różnorodne formy mieszkaniowo-opiekuńcze i mieszkaniowo-usługowe dla osób starszych i niepełnosprawnych. W niniejszej pracy autorka prezentuje efekt poszukiwań różnorodnych rozwiązań mieszkaniowych w postaci zwięzłej charakterystyki i tabelarycznej klasyfikacji zbiorczej, w której wyłoniono grupy o podobnych cechach, oraz przyporządkowano je do grup odbiorców o różnym stopniu sprawności i samodzielności życiowej. Ponadto autorka systematyzuje nazewnictwo występujące w publikacjach anglojęzycznych obejmujące kilkadziesiąt nazw oraz proponuje nazwy polskie dla wyłonionych grup specjalnych form mieszkaniowych oferujących pomoc lub opiekę stacjonarną dla osób starszych i niepełnosprawnych. W pracy zawarto także wnioski ogólne z prowadzonych badań w kontekście deficytu podobnych do prezentowanych rozwiązań na terenie Polski.

Słowa kluczowe: architektura mieszkaniowa, osoby starsze, niepełnosprawni, starzenie się społeczeństwa, pośrednie formy mieszkaniowe 